\title{
Complexes of Th(IV), Zr(IV) and V(IV) with Norfloxacin: Synthesis, Spectroscopic, Thermal, Kinetic Measurements and Antimicrobial Evaluation
}

\author{
Abdel Majid A. Adam \\ Department of Chemistry, Faculty of Science, Taif University \\ PO box 888, Taif, Saudi Arabia \\ Tel: 966-502-099-808 E-mail: majidadam@yahoo.com
}

Received: November 21, 2011 Accepted: December 6, $2011 \quad$ Published: January 1, 2012

doi:10.5539/jmsr.v1n1p167

URL: http://dx.doi.org/10.5539/jmsr.v1n1p167

\begin{abstract}
$\mathrm{M}(\mathrm{IV})$ complexes of thorium, zirconium, and vanadium with norfloxacin were synthesized and characterized with physical and spectroscopic techniques, including elemental analysis $(\mathrm{C}, \mathrm{H}, \mathrm{N}), \mathrm{IR}$, electronic, ${ }^{1} \mathrm{H}$ NMR spectral methods, as well as thermogravimetric (TG) and differential thermogravimetric (DTG) analyses. Based on these studies, the proposed structure of the obtained complexes are $\left[\mathrm{Th}(\mathrm{NFX})_{2} \mathrm{Cl}_{4}\right],\left[\mathrm{Zr}(\mathrm{NFX})_{2} \mathrm{Cl}_{2}\right] \mathrm{Cl}_{2}$ and $\left[\mathrm{VO}(\mathrm{NFX})_{2}\right] \mathrm{SO}_{4}$ (where, NFX: norfloxacin). In all complexes, norfloxacin acts as a bidentate deprotonated ligand bound to the metal through the pyridone and one carboxylate oxygen atoms, forming eight, six, five atoms ring with $\mathrm{Th}$ (IV), $\mathrm{Zr}(\mathrm{IV})$ and V(IV) metal ions, respectively. The kinetic thermodynamic parameters, such as, activation energy, $E^{*}$, enthalpy, $\Delta H^{*}$, entropy, $\Delta S^{*}$, and Gibbs free energy, $\Delta G^{*}$, have been calculated from the TG and DTG curves, using Coats-Redfern and Horowitz-Metzger methods. Norfloxacin as well as their metal complexes were also evaluated for their antibacterial activity against several bacterial species, such as Bacillus subtilis, Pseudomonas aeruginosa (P. aeruginosa), and Escherichia coli (E. coli) and antifungal screening was studied against three species: Aspergills flavus, Fusarium solani, and Penicillium verrcosum (P. verrcosum). The results show significant increase in antibacterial and antifungal activity of metal complexes as compared to the NFX itself.
\end{abstract}

Keywords: Norfloxacin complexes, Thermal analysis, Kinetic parameters, Antimicrobial evaluation

\section{Introduction}

Introduction of nalidixic acid during 1962 has shown the new avenue for patients with the bacterial infections and the dramatic impact in altering morbidity and mortality rate compared with the chemotherapy during 1940s. The continuous effort to increase the efficacy against bacteria has led to identify new prototype quinolone, which is active only against Gram-negative bacteria, similar to that of nalidixic acid (Sunduru et al., 2011). However, during 1980s, the introduction of fluoroquinolone drugs has changed the landscape of antibacterial chemotherapy, which was active against both Gram-negative and Gram-positive bacteria pathogens (Koga et al., 1980). Fluoroquinolones are broad-spectrum antibiotics widely used for the treatment of numerous diseases (Reynolds, 1993; Naumann \& Dopp, 1989). The most active fluoroquinolone drugs are Norfloxacin, Ciprofloxacin, Sparfloxacin, and Trovafloxacin. The antibacterial activity of fluoroquinolones depends not only on the bicyclic heteroaromatic pharmacophore but also on the nature of the peripheral substituent's and their spatial relationship (Koga et al., 1980;, Fang et al., 2000; Efthimiadou et al., 2007). These substituents exert their influence on antibacterial activity by providing additional affinity for the bacterial enzymes, enhancing the cell penetration, or altering the pharmacokinetics (Chu et al, 1986; Domagala et al, 1988). Norfloxacin (NFX, Fig. 1) (1-ethyl -6fluoro -4-oxo-7- (1-piperazinyl) -1,4-dihydroquinoline- 3- carboxylic acid) is a second generation fluoroquinolone, and widely used representative member of this family (Dhaneshwar et al, 2001). It is antibiotic agent that extensively used in both human and veterinary medicine (Cui et al., 2011). Norfloxacin (NFX) is active against a wide variety of aerobic Gram-negative and Gram-positive bacteria but specifically, active against aminoglycoside-resistant Pseudomonas aeruginosa and betalactamase producing organisms (Shaikh et al., 2007). When dealing with the interaction between drugs and metal ions in living systems, a particular interest has been given to the interaction of metal ions with antibiotics. Presence of metal ions considerably alters the activity of 
fluoroquinolones against potentially susceptible bacteria (Shaikh et al., 2007). A number of works have been reported about the synthesis and characterization of new metal complexes with fluoroquinolone antibacterial agents (Shaikh et al., 2007; Turel et al., 1997a; Turel et al., 1998; Wu et al., 2003; Refat, 2007; Al-Mustafa, 2002; Sadeek et al., 2006; Polk \& Pharm, 1989).

In this paper, the interaction of norfloxacin (NFX) with tetraverse transition metal ions in an attempt to examine the mode of norfloxacin coordination and the biological properties of the resulting complexes. In particular, complexes of NFX with the Th(IV), Zr(IV), and V(IV) have been synthesized and characterized with elemental analysis, infrared (IR), 1H NMR and electronic spectra. The thermal behavior of the obtained complexes has also been studied as well as their biological activity against several microorganisms. The antibacterial activity was tested against Bacillus subtilis, Pseudomonas aeruginosa (P. aeruginosa), and Escherichia coli (E. coli) and antifungal screening was studied against three species: Aspergills flavus, Fusarium solani, and Penicillium verrcosum ( $P$. verrcosum).

\section{Materials and Methods}

\subsection{Materials}

All chemicals used were of analytical reagent grade, commercially available, and were used without further purification. Egyptian Interactional Pharmaceutical Industrial Company (EIPICO) supplied Norfloxacin used in this work. $\mathrm{Th}\left(\mathrm{NO}_{3}\right)_{4}, \mathrm{ZrCl}_{4} \cdot \mathrm{xH}_{2} \mathrm{O}$, and $\mathrm{VOSO}_{4} \cdot 5 \mathrm{H}_{2} \mathrm{O}$ were purchased from Aldrich Chemical Company.

\subsection{Synthesis of the metal complexes}

Norfloxacin $(2 \mathrm{mmol})$ in mixed solvent $(50 / 50 \%)$ of methanol/acetone was stirred at room temperature for 20 min. A solution of $1.0 \mathrm{mmol}$ of $\mathrm{Th}\left(\mathrm{NO}_{3}\right)_{4}, \mathrm{ZrCl}_{4}$, and $\mathrm{VOSO}_{4}$ in $5 \mathrm{ml}$ of methanol was added to the norfloxacin solution with constant stirring. The resulting mixture was heated $\sim 50{ }^{\circ} \mathrm{C}$ under reflux on a water bath for about $12 \mathrm{~h}$ and then cooled. The resulted solid complexes were separated from the reaction mixture by filtration, washed with methanol and dried under vacuum to a constant weight. The yields were found around $70 \%$ based on the metal salts. The compounds resulted have low solubility in water and in common organic solvents. The obtained complexes were characterized by their elemental analysis, infrared, electronic, and ${ }^{1} \mathrm{H}$ NMR, as well as thermal analysis.

\subsection{Instrumentation and physical measurements}

\subsubsection{Elemental analysis}

Elemental analysis was performed using a Perkin-Elmer CHN 2400, and the metal contents were found gravimetrically by ignition-weighted samples in atmospheric air to constant weight and definite structure.

Decomposition of complexes was performed in concentrated $\mathrm{HNO}_{3}$. After decomposition, the sample was diluted with water to $100 \mathrm{ml}$, and qualitative presence of $\mathrm{Cl}^{-}$ions (in $\mathrm{Th}(\mathrm{IV}) \mathrm{Zr}(\mathrm{IV})$ complexes), and $\mathrm{SO}_{4}{ }^{-}$ions (in $\mathrm{V}\left(\mathrm{IV}\right.$ ) complex) were determined by means of $\mathrm{AgNO}_{3}$ and $\mathrm{BaCl}_{2}$, respectively.

\subsubsection{Molar conductivity}

Molar conductivities of freshly prepared $10^{-3} \mathrm{~mol} \mathrm{dm}^{-3}$ DMSO solutions were measured on a Jenway 4010 conductivity meter.

\subsubsection{Electronic spectra}

Electronic spectra were recorded in the region of $(200-800 \mathrm{~nm})$ for DMSO solution $\left(10^{-3}\right)$ of the NFX and their three complexes with Shimadzu UV-spectrophotometer model 1601 PC with a $1 \mathrm{~cm}$ quartz cell.

\subsubsection{Infrared spectra}

Infrared (IR) measurements were carried out on a Genesis II FT-IR spectrophotometer using KBr pellets in the $\mathrm{v}=400-4000 \mathrm{~cm}^{-1}$ range.

\subsection{5 ${ }^{1} \mathrm{H}$ NMR spectra}

${ }^{1} \mathrm{H}$ NMR spectra of Thorium complex was obtained on a Varian Gemini $200 \mathrm{MHz}$ spectrometer using DMSO-d6 as solvent and TMS as an internal reference. ${ }^{1} \mathrm{H}$ NMR data are expressed in parts per million (ppm), referenced internally to the residual proton impurity in DMSO solvent.

\subsubsection{Thermal analysis}

Thermogravimetric measurements (TG and DTG) were carried out in dynamic nitrogen atmosphere $(30 \mathrm{ml} / \mathrm{min}$.) between room temperature and $900{ }^{\circ} \mathrm{C}$ with a heating rate of $10{ }^{\circ} \mathrm{C} / \mathrm{min}$. using a Shimadzu TGA $-50 \mathrm{H}$ thermal analyzers. 


\subsection{Antimicrobial investigation}

Antibacterial activity of the Th(IV), Zr(IV), and V(IV) complexes, and the NFX ligand, as well as the pure solvent was investigated by a previously reported modified method of Beecher and Wong (Beecher \& Wong, 1994), against different bacterial species, such as Escherichia coli (E. coli), Bacillus subtilis, and Pseudomonas aeruginosa (P. aeruginosa), and antifungal screening was studied against three species, Aspergills flavus, Fusarium solani, and Penicillium verrcosum (P. verrcosum). The microorganisms were purchased from the laboratory of (Microbiology) in the Egyptian International Pharmaceutical Industrial Company (EIPICO).

\section{Results and Discussion}

The results of the elemental analysis and some physical characteristics of NFX ligand and the obtained complexes are given in Table 1 (Note 1.). The complexes were synthesized using 1:2 (metal: ligand) mole ratio of all reactants. The elemental analysis (Table 1) of the complexes indicates a 1:2 metal to ligand stoichiometry, too. All complexes are stable in air, hygroscopic, with high melting points, insoluble in water, but partly soluble in dimethylformamide; DMF. All complexes have been prepared at high yield (73-76\%), and melting points of the complexes are higher than that of the ligand revealing that the complexes are much more stable than ligand. The molar conductance values (Table 1) of the complexes in DMF solvent $\left(10^{-3} \mathrm{~mol} \mathrm{dm}^{-3}\right)$ lay in the range of 73.00-87.20 $\Omega^{-1} \mathrm{~cm}^{2} \mathrm{~mol}^{-1}$ (at $25^{\circ} \mathrm{C}$ ), which indicates that the complexes are electrolytes, and the complexes are of much increasing in electrolytic nature than NFX ligand. The low conductivity values are in agreement with the low solubility of NFX complexes in water, ethanol, chloroform, acetone and most organic solvents. On the other hand, they are soluble in DMSO and DMF. The proposed structures of the obtained complexes are shown in Fig. 2. These structures were confirmed by its analytical data.

\subsection{Infrared spectra}

The IR spectra of quinolones are most representative in the region 1800-1300 $\mathrm{cm}^{-1}$ (Turel et al., 1997b). The tentative assignments of IR bands of $\mathrm{Th}(\mathrm{IV}), \mathrm{Zr}(\mathrm{IV})$, and $\mathrm{V}(\mathrm{IV})$ complexes are presented in Table 2 (Note 2. and 3.) and Fig. 3, and have been compared with those of the free ligand norfloxacin, in order to determine the site of coordination that may be involved in chelation.

(i) The IR spectral data of NFX (Table 2) showed two characteristic peaks at $1716 \mathrm{~cm}^{-1}$ (characteristic of the $\mathrm{v}(\mathrm{C}=\mathrm{O})_{\text {carb }}$ stretching vibration of the carboxylic group), and $1630 \mathrm{~cm}^{-1}$ (attributed to the $\mathrm{v}(\mathrm{C}=\mathrm{O})_{\mathrm{p}}$ of pyridone keto) (Sadeek, 2005; Sadeek et al, 2009).

(ii) $\mathrm{Th}(\mathrm{IV}), \mathrm{Zr}(\mathrm{IV}), \mathrm{V}(\mathrm{IV})$ complexes shows no absorption band at $\sim 1700 \mathrm{~cm}^{-1} v(\mathrm{C}=\mathrm{O})$, that is indicative of the deprotonation of $-\mathrm{COOH}$ group and involvement of the carboxyl group in the formation of Th-O, $\mathrm{Zr}-\mathrm{O}$, and $\mathrm{V}-\mathrm{O}$ bonds.

(iii) The $\mathrm{v}(\mathrm{C}=\mathrm{O})_{\mathrm{p}}$ peak (of pyridone keto) is shifted from $1630 \mathrm{~cm}^{-1}$ in the ligand to lower frequencies in the complexes $\left(\sim 1610-1617 \mathrm{~cm}^{-1}\right)$ upon bonding.

(iv) The spectra of the three complexes shows two very strong to strong characteristic bands $\left(\sim 1575 \mathrm{~cm}^{-1}\right.$ and 1380) at $1576-1380,1579-1382,1583-1381 \mathrm{~cm}^{-1}$ for $\mathrm{Th}(\mathrm{IV}), \mathrm{Zr}(\mathrm{IV}), \mathrm{V}(\mathrm{IV})$ complexes, respectively, assigned as $v(\mathrm{O}-\mathrm{C}-\mathrm{O})$ asymmetric and symmetric stretching vibrations of the ligated carboxylate anion, respectively. These bands are weak in the spectrum of NFX. These complexes also have medium intensity peak around $~ 1450$ $\mathrm{cm}^{-1}$ that correspond to asymmetrical and symmetrical carboxylate anion stretching.

Deacon and Phillips, 1980, have studied the criteria that can be used to distinguish between the three binding states of the carboxylate complexes. These criteria are: (a) $\Delta v>200 \mathrm{~cm}^{-1}$ (where $\Delta v=\left[\operatorname{vas}\left(\mathrm{COO}^{-}\right)-v \mathrm{~s}\left(\mathrm{COO}^{-}\right)\right]$) this relation was found in case of monodentate carboxylato complexes, (b) bidentate or chelating carboxylato complexes exhibit $\Delta v$ significantly smaller than ionic values $\left(\Delta v<100 \mathrm{~cm}^{-1}\right)$, and finally, (c) bridging complexes show $\Delta v$ comparable to ionic values $\left(\Delta v \sim 150 \mathrm{~cm}^{-1}\right)$. Therefore, the difference value $\Delta v$ is a useful characteristic for determining the coordination mode of the carboxylate group of the ligands. The observed $\Delta v$ for Th(IV), $\mathrm{Zr}(\mathrm{IV})$, and V(IV) complexes (Table 3, Note 4. and 5.) fall in the range 196-202 $\mathrm{cm}^{-1}$ indicating a monodentate coordination mode of the carboxylato group (Dendrinou-Samara et al., 1998; Nakamoto, 1986) .

(v) The IR spectral data of the three complexes show medium-to-medium-weak bands around $3390 \mathrm{~cm}^{-1}$, and weak to very weak band at 2933-2375, 2845-2356, and 2883-2344 for $\operatorname{Th}(\mathrm{IV}), \mathrm{Zr}(\mathrm{IV})$, and V(IV) complexes, respectively. These bands can be assigned to the vibrations of the quaternized nitrogen $\left({ }^{+} \mathrm{NH}_{2}\right)$ of the piperazinyl group, which indicated that the zwitterionic form of NFX is involved in the coordination of the Th, Zr, and V ion investigated (Silverstein et al., 1991).

(vi) The vibrations of the free sulphate group in V(IV) complex, $\left[\mathrm{VO}(\mathrm{NFX})_{2}\right] \mathrm{SO}_{4}$, can be assigned as follows: 
two weak intensities bands occur in the region above $1000 \mathrm{~cm}^{-1}$ at 1195 and $1036 \mathrm{~cm}^{-1}$, are assigned to the different symmetric and antisymmetric bond vibrations, $\mathrm{v}\left(\mathrm{SO}_{4}{ }^{2-}\right)$, and medium strong band at $689 \mathrm{~cm}^{-1}$ is assigned to the bending motion of $\delta\left(\mathrm{SO}_{4}{ }^{2-}\right)$.

(vii) The $\mathrm{v}(\mathrm{V}=\mathrm{O})$ stretching vibration in the vanadyl complex is observed as expected as a medium band at 956 $\mathrm{cm}^{-1}$, which is a good agreement with those known for many dioxovanadium (IV) complexes.

According to the IR spectral data, the NFX is coordinated to the metal ions as a bidentate ligand via one-carboxylato oxygen atoms and the oxygen atom of the pyridine carbonyl group (Turel, 2002).

\subsection{Electronic absorption spectra}

Electronic spectra of the NFX complexes were recorded in the 200-800 nm region in DMSO (Fig. 4) There are two detected absorption bands at 285 and $335 \mathrm{~nm}$ in electronic spectrum of NFX, assigned to $\mathrm{n}-\pi^{*}$ and $\pi-\pi^{*}$ transitions. These transitions occur in case of unsaturated hydrocarbons, which contain carbon atom attached with oxygen atoms as in carboxylic and ketone groups (Refat, 2007). The electronic spectra of $\operatorname{Th}(\mathrm{IV}), \mathrm{Zr}(\mathrm{IV})$, and V(IV) complexes show two absorption bands at 250 and $285 \mathrm{~nm}$. The band at $335 \mathrm{~nm}$ is absent in the electronic spectra of the complexes which may indicate that the carboxylic group and ketone groups are involved in the complexation.

\section{$3.3{ }^{1} H$ NMR spectra}

The ${ }^{1} \mathrm{H}$ NMR spectral data of the $\left[\mathrm{Th}(\mathrm{NFX})_{2} \mathrm{Cl}_{4}\right]$ complexes and the free ligand (NFX) are represented in Table 4, and all assignments. The spectrum of the complex is shown in Fig. 5. The literature values of the ${ }^{1} \mathrm{H}$ NMR chemical shifts $(\delta, \mathrm{ppm})$ of NFX are included in Table 4 for comparison purposes. Upon comparison with the free ligand, the absent of the characteristic peak for hydrogen of $-\mathrm{COOH}$ at $\delta 11.00 \mathrm{ppm}$ in $\mathrm{Th}(\mathrm{IV})$ complex indicates coordination of NFX ligand to Th(VI) through the deprotonated carboxylic group (Refat, 2007; Sadeek, 2005). The spectrum also show characteristic three peaks for quaternized nitrogen $\left({ }^{+} \mathrm{NH}_{2}\right)$ at $\delta 2.10,2.50$, and $3.9 \mathrm{ppm}$ (Sadeek et al., 2009). The broad peak at $\delta 3.9 \mathrm{ppm}$, which was not detected in the spectra of free NFX ligand, confirmed the deprotonation of the two - $\mathrm{COOH}$ groups in NFX. The overall changes of the ${ }^{1} \mathrm{H}$ NMR spectrum of the Th (IV) complex is indicative of coordination of NFX ligand to the metal via the pyridone and one carboxylate oxygen atoms (Riley et al., 1993). This suggested coordination is in agreement with that obtained by elemental analysis and IR spectra.

\subsection{Thermogravimetric analysis}

The Norfloxacin of T(IV), Zr(IV), and V(IV) complexes are stable at room temperature and can be stored for several months without any changes. The obtained complexes were studied by thermogravimetric (TG) and differential thermogravimetric (DTG) analysis from ambient temperature to $900{ }^{\circ} \mathrm{C} \mathrm{N}_{2}$ atmospheres. The TG curves were redrawn as mg mass loss versus temperature (TG) curves and as the rate of loss of mass versus temperature (DTG) curves. Typical TG and DTG curves are presented in Fig. 6, and the thermoanalytical results are summarized in Table 5. The overall loss of mass from the TG curves is $97.74 \%$ for NFX, $68.64 \%$ for $\left[\mathrm{Th}(\mathrm{NFX})_{2} \mathrm{Cl}_{4}\right], 86.28 \%$ for $\left[\mathrm{Zr}(\mathrm{NFX})_{2} \mathrm{Cl}_{2}\right] \mathrm{Cl}_{2}$, and $85.12 \%$ for $\left[\mathrm{VO}(\mathrm{NFX})_{2}\right] \mathrm{SO}_{4}$. All the complexes show two or three stages of mass loss in their TG/DTG curves, and all mass loss in these stages is due to the decomposition of counter ions and NFX molecules.

\subsubsection{Norfloxacin ligand}

The data obtained indicate that the NFX is thermally stable in the temperature range $25-50{ }^{\circ} \mathrm{C}$. Decomposition of NFX start at $50{ }^{\circ} \mathrm{C}$ and finished at $726^{\circ} \mathrm{C}$ with three stages. The first stage of decomposition occurs between 25 and $270{ }^{\circ} \mathrm{C}$, at maximum temperature of $125^{\circ} \mathrm{C}$, and is accompanied by weight loss of $8.38 \%$, corresponding exactly to the loss of ethylene molecule $\left(\mathrm{C}_{2} \mathrm{H}_{2}\right)$. The second stage of decomposition starts at $270{ }^{\circ} \mathrm{C}$ and end at $575{ }^{\circ} \mathrm{C}$, showing an endothermic peak at $335{ }^{\circ} \mathrm{C}$. This stage is accompanied by a weight loss of $69.80 \%$, corresponding to the loss of $4 \mathrm{C}_{2} \mathrm{H}_{2}+\mathrm{HF}+\mathrm{N}_{2}+\mathrm{CO}+\mathrm{CO}_{2}$. The final decomposition step occurs in the range $575-720{ }^{\circ} \mathrm{C}$ with a maximum at $650{ }^{\circ} \mathrm{C}$, and is accompanied by a weight loss of $19.56 \%$, and my be attributed to the loss of pyrrole ring, $2 \mathrm{C}_{2} \mathrm{H}_{2}+1 / 2 \mathrm{~N}_{2}, 1 / 2 \mathrm{H}_{2}$, in reasonable agreement with the theoretical value of $21.0 \%$.

\subsection{2 $\left[\mathrm{Th}(\mathrm{NFX})_{2} \mathrm{Cl}_{4}\right]$ complex}

The thermal decomposition of $\left[\mathrm{Th}(\mathrm{NFX})_{2} \mathrm{Cl}_{4}\right]$ complex proceeds approximately with three main degradation stages in $25-900{ }^{\circ} \mathrm{C}$ temperature range. The first stage of decomposition is exothermic stage occurs at three maximum temperature of 50,108 , and $218^{\circ} \mathrm{C}$, and is accompanied by a weight loss of $11.84 \%$, corresponding to the loss of $2 \mathrm{C}_{2} \mathrm{H}_{2}+\mathrm{Cl}_{2}$. The second stage of decomposition occurs at three maximum temperatures at 308,377 , and $455^{\circ} \mathrm{C}$. The weight loss in this step is $37.69 \%$, corresponding to the loss of $5 \mathrm{C}_{2} \mathrm{H}_{2}+\mathrm{Cl}_{2}+2 \mathrm{HF}+2 \mathrm{~N}_{2}+2 \mathrm{NO}$ 
$+2 \mathrm{CO}$. The final step is associated with the loss of $7 \mathrm{C}_{2} \mathrm{H}_{2}+\mathrm{CO}+4 \mathrm{H}_{2}$ forming $\mathrm{ThO}_{2}+4 \mathrm{C}$ as a final product.

\subsection{3 $\left[\mathrm{Zr}(\mathrm{NFX})_{2} \mathrm{Cl}_{2}\right] \mathrm{Cl}_{2}$ complex}

The thermal analysis curves of $\left[\mathrm{Zr}(\mathrm{NFX})_{2} \mathrm{Cl}_{2}\right] \mathrm{Cl}_{2}$ complex show that decomposition takes places in two stages. The first stage is exothermic stage occurs at two maximum temperature at 60 and $298{ }^{\circ} \mathrm{C}$. The broader exothermic peak at $60{ }^{\circ} \mathrm{C}$ indicate a slow in heat capacity (Shaikh et al., 2007). The weight loss in this stage is $17.61 \%$ in the $25-250$ range corresponding to the loss of $2 \mathrm{C}_{2} \mathrm{H}_{2}+3 / 2 \mathrm{Cl}_{2}$. The following stage occurs at maximum temperature of $553{ }^{\circ} \mathrm{C}$ in the temperature range $250-900$ corresponding to the formation of $13 \mathrm{C}_{2} \mathrm{H}_{2}+$ $1 / 2 \mathrm{Cl}_{2}+2 \mathrm{HF}+2 \mathrm{~N}_{2}+2 \mathrm{NO}+2 \mathrm{CO}+2 \mathrm{H}_{2}$. The final thermal product obtained at $900{ }^{\circ} \mathrm{C}$ is $\mathrm{ZrO}_{2}$.

\subsection{4 $\left[\mathrm{VO}(\mathrm{NFX})_{2}\right] \mathrm{SO}_{4}$ complex}

Thermal decomposition of $\left[\mathrm{VO}(\mathrm{NFX})_{2}\right] \mathrm{SO}_{4}$ proceeds in three stages. The first stage is occurs at maximum temperature at $60{ }^{\circ} \mathrm{C}$ (DTG), in the temperature range $25-210{ }^{\circ} \mathrm{C}$. The mass loss in this stage is found to be $14.81 \%$, corresponding to the thermal decomposition of the complex by the loss of $2 \mathrm{C}_{2} \mathrm{H}_{2}+\mathrm{SO}_{2}$. This is followed by another mass loss $\left(68.38 \%\right.$ ) in the temperature range $210-520^{\circ} \mathrm{C}$, by giving an endothermic effect $\left(\mathrm{DTG}_{\max }, 260,374,445^{\circ} \mathrm{C}\right.$ ). In the final stage, the complex decomposes in consecutive steps in the $520-900{ }^{\circ} \mathrm{C}$ temperature range to give $\mathrm{VO}_{2.5}$ with some carbon atoms.

Reported data on thermal analysis studies in the nitrogen atmosphere indicate that the $\mathrm{Th}(\mathrm{IV}), \mathrm{Zr}(\mathrm{IV}), \mathrm{V}(\mathrm{IV})$ complexes decompose to give metal oxide as final product, with few carbon atoms (except $\mathrm{Zr}$ (IV) complex), indicates that no sufficiently of oxygen atoms helps to evolved carbon as carbon monoxide or dioxide. The found weight loss associated with each step of decomposition for each complex agrees well with the calculated weight loss (Table 5). The final products of the complexes obtained at $900{ }^{\circ} \mathrm{C}$ were confirmed with infrared spectra.

\subsection{Kinetic parameters}

Two methods of decomposition kinetics studies have been applied in this study; Coats-Redfern (Coats \& Redfern, 1964) and Horowitz-Metzger (Horowitz \& Metzger, 1963).

\subsubsection{Coats-Redfern equation}

The Coats-Redfern equation (1), which is atypical integral method, can be represented as:

$$
\int d \alpha /(1-\alpha)^{n}=(A / \varphi) \int e^{-E^{*} / R T} d T
$$

For convenience of integration, the lower limit $\mathrm{T} 1$ is usually taken as zero. This equation on integration gives:

$$
\ln \left[-\ln (1-\alpha) / T^{2}\right]=-E^{*} / R T+\ln [A R / \varphi E]
$$

A plot of left-hand side (LHS) against $1 / \mathrm{T}$ was drawn. $E^{*}$ is the energy of activation in $\mathrm{KJ} \mathrm{mol}^{-1}$ and calculated from the slop and $A$ in $\left(\mathrm{s}^{-1}\right)$ from the intercept. The entropy of activation $\Delta S^{*}$ in $\left(\mathrm{JK}^{-1} \mathrm{~mol}^{-1}\right)$ was calculated by using the equation:

$$
\Delta S^{*}=R \ln \left(A h / k T_{s}\right)
$$

where $k$ is the Boltzmann constant, $h$ is the Plank's constant and $T_{s}$ is the DTG peak temperature.

\subsubsection{Horowitz-Metzger equation}

The Horowitz-Metzger (Eg. 4) was written in the form as follows:

$$
\log \left[\log \left(w_{\alpha} / w_{\gamma}\right)\right]=E^{*} \theta / 2.303 R T_{s}^{2}-\log 2.303
$$

Where $\theta=T-T_{\mathrm{s}}, w_{\gamma}=w_{\alpha}-w, w_{\alpha}=$ mass loss at the completion of the reaction; $w=$ mass loss up to time $t$.

The plot of $\log \left[\log \left(w_{\alpha} / w_{\gamma}\right)\right]$ versus $\theta$ was drawn and found to be linear from the slope $E^{*}$ was calculated. The pre-exponential factor, $A$, was calculated from the Eg. (5):

$$
E^{*} \theta / R T_{s}^{2}=A /\left[\varphi \exp \left(-E^{*} / R T_{s}\right)\right]
$$

From the TG curves, the activation energy, $E^{*}$, entropy of activations, $\Delta S^{*}$, enthalpy activations, $\Delta H^{*}$, and Gibbs free energy, $\Delta G^{*}$, were calculate from;

$\Delta H^{*}=E^{*}-R T$ and $\Delta G^{*}=\Delta H^{*}-T \Delta S^{*}$

The linearization curves of Coats-Redfern and Horowitz-Metzger methods are shown in Fig 7. Kinetic parameters for the first stages, calculated by employing Coats-Redfern and Horowitz-Metzger equations, are summarized in Table 6 (Note 6.), together with the radii metal ions. The results show that the values obtained by various methods are comparable. The kinetic data obtained with the two methods are in harmony with each other. The activation energy of $\mathrm{Th}(\mathrm{IV}), \mathrm{Zr}(\mathrm{IV})$ and $\mathrm{V}(\mathrm{IV})$ complexes is expected increase in relation with decrease in 
their radius (Avsar et al., 2002). The $E^{*}$ values calculated with the method of Coats-Redfern for the first decomposition stage of the complexes are given below:

$E^{*} \mathrm{~V}(\mathrm{IV})=1.73 \times 10^{5} \mathrm{kJmol}^{-1}>E^{*} \mathrm{Zr}(\mathrm{IV})=1.38 \times 10^{5} \mathrm{kJmol}^{-1}>E^{*} \mathrm{Th}(\mathrm{IV})=8.19 \times 10^{4} \mathrm{kJmol}^{-1}$

$\mathrm{rV}(\mathrm{IV})=72 \mathrm{pm}<\mathrm{rZr}(\mathrm{IV})=86 \mathrm{pm}<\mathrm{rTh}(\mathrm{IV})=108 \mathrm{pm}$

3.6 Antimicrobial activities

Applying the nutrient filter paper disc method, all of the newly synthesized NFX complexes and NFX were screened in vitro for antibacterial and antifungal activity. The activity was determined against three bacterial species, Bacillus subtilis, Pseudomonas aeruginosa (P. aeuginosa), and Escherichia coli (E. coli), and antifungal screening was studied against three species, Aspergills flavus, Fusarium solani, and Penicillium verrcosum. The activity was performed by measuring the diameter of the inhabitation zone, and the screening results are given in Table 7 (Note 7.). The results show that the metal complexes are more effective as antibacterial and antifungal agents as compared to the uncomplexed ligand. This increase in the activity is being considered due to increased bioavailability of the metal drug complexes and the aqueous solubility of NFX. Th(IV) complex exhibit higher activity than other complexes. All the three complexes exhibited no inhibitory activates against Bacillus subtilis species.

\section{Conclusion}

Transport of organic ligands into bacterial cells can be facilitated by the formation of metal complexes. Hence, $\mathrm{Th}(\mathrm{IV}), \mathrm{Zr}(\mathrm{IV})$ and $\mathrm{V}(\mathrm{IV})$ complexes of norfloxacin were synthesized. UV, IR, $1 \mathrm{H}$ NMR, elemental analysis and thermogravimetric analysis (TG) and differential thermal analysis (DTG), characterized the isolated solid complexes. In all the complexes, norfloxacin is bound to the metal via the pyridone and one carboxylate oxygen atoms, and the complexes are found to possess metal to ligand ratio of 1:2. Antimicrobial studies were carried out against several types of bacteria and fungi. Th(IV), $\mathrm{Zr}(\mathrm{IV})$ and V(IV) complexes are found to possess better activity against all the microorganisms tested (except Bacillus subtilis species), than that of norfloxacin. It was concluded that the obtained complexes could be better alternative to norfloxacin as an antibacterial and antifungal agent.

\section{Acknowledgements}

The author is deeply grateful to the member staff of Department of Microbiology, Egyptian International Pharmaceutical Industrial Company (EIPICO), for performing the antimicrobial evaluation.

\section{References}

Al-Mustafa, J. (2002). Magnesium, calcium and barium perchlorate complexes of ciprofloxacin and norfloxacin. Acta Chimica Slovenica, 49, 457-470.

Avsar, G., Kulcu, N., \& Arslan, H. (2002). Thermal behavior of copper(II), nickel(II), cobalt(II) and palladium(II) complexes of N, N-dimethyl-N'-benzoylthiourea. Turkish Journal of Chemistry, 26, 607-616.

Beecher, D. J., \& Wong, A. C. (1994). Identification of hemolysin BL-producing Bacillus cereus isolates by a discontinuous hemolytic pattern in blood agar. Applied and Environmental Microbiology, 60, 5, 1646-1651.

Chu, D. T. W., Fernandes, P. B., \& Perent, A. G. (1986). Synthesis and biological activity of benzothiazolo [3, 2-a] quinolone antibacterial agents. Journal of Medicinal Chemistry, 29, 1531. http://dx.doi.org/1021/jm00158a037

Coats, A. W., \& Redfern, J. P. (1964). Kinetic Parameters from Thermogravimetric Data. Nature, 201, 68. http://dx.doi.org/10.1038/201068a0

Cui, J., Zhang, K., Huang, Q., Yu, Y., \& Peng, X. (2011). An indirect competitive enzyme-linked immunosorbent assay for determination of norfloxacin in waters using a specific polyclonal antibody. Analytica Chimica Acta, 688, 84-89. http://dx.doi.org/10.1016/j.aca.2010.12.030

Deacon, G. B., \& Phillips, R. J. (1980). Relationships between the carbon-oxygen stretching frequencies of carboxylato complexes and the type of carboxylate coordination. Coordination Chemistry Reviews, 33, 227-250. http://dx.doi.org/10.1016/S0010-8545(00)80455-5

Dendrinou-Samara, C., Tsotsou, G., Ekateriniadou, L. V., Kortsaris, A. H., Raptopoulou, C. P., Terzis, A., Kyriakidis, D. A., \& Kessissoglou, D. P. (1998). Anti-inflammatory drugs interacting with $\mathrm{Zn}(\mathrm{II}), \mathrm{Cd}(\mathrm{II})$ and $\mathrm{Pt}(\mathrm{II})$ metal ions. Journal of Inorganic Biochemistry, 71, 171-179.

Dhaneshwar, S., Tewari, K., Joshi, S., Godbole, D., \& Ghosh, P. (2001). Diglyceride prod rug strategy for 
enhancing the bioavailability of norfloxacin. Chemistry and Physics of Lipids, 164, 307-313. http://dx.doi.org/10.1016/j.chemphyslip.2011.03.006

Domagala, J. M., Heifetz, C. L., Hutt, M. P., Mich, T. F., Nichols, J. B., Solomon, M., \& Worth, D. F. (1988). 1-Substituted 7-[3-ethylamino) methyl] -1- pyrrolidinyl] -6,8-difluoro -1,4-dihydro -4- oxo -3-quindine carboxylic acids. New quantitative structure activity relationships at $\mathrm{N} 1$ for the quinolone antibacterials. Journal of Medicinal Chemistry, 31, 991-1001. http://dx.doi.org/10.1021/jm00400a017

Efthimiadou, E. K., Psomas, G., Sanakis, Y., Katsaros, N., \& Karaliota, A. (2007). Metal complexes with the quinolone antibacterial agent $N$-propyl-norfloxacin: Synthesis, structure and bioactivity. Journal of Inorganic Biochemistry, 101, 525-535. http://dx.doi.org/10.1016/j.jinorgbio.2006.11.020

Fang, K. -C., Chen, Y. -L., Sheu, J. -Y, Wang, T. -C, \& Tzeng, C. -C. (2000). Synthesis, Antibacterial, and Cytotoxic Evaluation of certain 7-substitued Norfloxacin Derivatives. Journal of Medicinal Chemistry, 43, 3809-3812. http://dx.doi.org/10.1021/jm000153x

Horowitz, H. H., \& Metzger, G. (1963). A New Analysis of Thermogravimetric Traces. Analytical Chemistry, 35, 1464-1468. http://dx.doi.org/10.1021/ac60203a013

Koga, H., Itoh, A., Murayama, S., Suzue, S., \& Irikura, T. (1980). Structure-activity relationships of antibacterial 6, 7-and, 8-disubstituted 1-alkyl-1, 4-dihydro-4-oxoquinoline-3-carboxylic acids. Journal of Medicinal Chemistry, 23, 1358-1363. http://dx.doi.org/10.1021/jm00186a014

Nakamoto, K. (1986). Infrared and Ramman Spectra of Inorganic and Coordination Compounds. (4th ed.). New York: Wiley. pp. 230.

Naumann, P., \& Dopp, C. (1989). Fluoroquinolones-antibacterial activity, pharmacokinetics and indications for a new group of chemotherapeutic drugs. Internist (Berl.) 30, 20-31.

Polk, R. E., \& Pharm, D. (1989). Drug-drug interactions with ciprofloxacin and other fluoroquinolones. The American Journal of Medicine, 87, 76-81. http://dx.doi.org/10.1016/0002-9343 (89)90028-4

Refat, M. S. (2007). Synthesis and characterization of norfloxacin-transition metal complexes (group 11, IB): Spectroscopic, thermal, kinetic measurements and biological activity. Spectrochimica Acta Part A, 68, 1393-1405. http://dx.doi.org /10.1016/j.saa.2006.12.078

Reynolds, J. E. (Ed.), (1993). Martindale: The Extra Pharmacopeia. (30rd ed.). London: Pharmaceutical Press, pp. 145-147.

Riley, C. M., Ross, D. L., van der Velde, D., \& Takusagawa, F. (1993). Characterization of the complexation of fluoroquinolone antimicrobials with metal ions by nuclear magnetic resonance spectroscopy. Journal of Pharmaceutical and Biomedical Analysis, 11, 49-59. http://dx.doi.org/doi: 10.1016/0731-7085(93)80148-T

Sadeek, S. A. (2005). Synthesis, thermogravimetric analysis, infrared, electronic and mass spectra of Mn(II), $\mathrm{Co}(\mathrm{II})$ and $\mathrm{Fe}(\mathrm{III})$ norfloxacin complexes. Journal of Molecular Structure, 753, 1-12. http://dx.doi.org/10.1016/j.molstruc.2005.06.011

Sadeek, S. A., El-Did Amony, A. M., El-Shwiniy, W. H., \& Zordok, W. A. (2009). Uranium (VI) and zirconium (IV) of the second-generation quinolone antimicrobial drug norfloxacin: Structure and biological activity. The Journal of Argentine Chemical Society, 97, 2, 51-76.

Sadeek, S., A., El-Shwiniy, W., H., Zordok, W., A., \& El-Didamony, A., M. (2009). Synthesis, spectroscopic, thermal and biological activity investigation of new Y(III) and Pd(II) norfloxacin complexes. The Journal of the Argentine Chemical Society, 97, 2, 128-148.

Sadeek, S. A., Refat, M. S., \& Hashem, H. A. (2006). Complexation and thermogravimetric investigation on tin(II) and tin(IV) with norfloxacin as antibacterial agent. Journal of Coordination Chemistry, 7, 759-775. http://dx.doi.org/10.1080/00958970500404534

Shaikh, A. R., Giridhar, R., \& Yadav, M. R. (2007). Bismuth-norfloxacin complex: Synthesis, physicochemical and antimicrobial evaluation. International Journal of Pharmaceutics, 332, 24-30. http://dx.doi.org/10.1016/j.ijpharm.2006.11.037

Silverstein, R. M., Bassler, G., C., \& Morril, T. C. (1991). Spectroscopic Identification of Organic Compounds, (5th ed.). New York: Wiley.

Sunduru, N., Gupta, L., Chauhan, K., Mishra, N. N., \& Shukla, P. K. (2011). Synthesis and antibacterial evaluation of novel 8-fluoro Norfloxacin derivatives as potential probes for methicillin and vancomycin-resistant 
Staphylococcus aureus. European Journal of Medicinal Chemistry, 46, 1232-1244. http://dx.doi.org/10.1016/j.ejmech.2011.01.044

Turel, I. (2002). The interaction of metal ions with quinolone antibacterial agents. Coordination Chemistry Reviews, 232, 27-47.

Turel, I., Leban, I., \& Bukovec, N. (1997a). Crystal Structure and Characterization of the Bismuth (III) Compound with Quinolone Family Member (Ciprofloxacin), Antibacterial Study. Journal of Inorganic Biochemistry, 66, 241-245.

Turel, I., Bukovec, P., \& Quirós, M. (1997b). Crystal structure of ciprofloxacin hexahydrate and its characterization. International Journal of Pharmaceutics, 152, 59-65.

Turel, I., Golic, L., Bukovec, P., \& Gubina, M. (1998). Antibacterial tests of Bismuth (III)-Quinolone (Ciprofloxacin, cf) compounds against Helicobacter pylori and some other bacteria. Crystal structure of $\left(\mathrm{cfH}_{2}\right)_{2}\left[\mathrm{Bi}_{2} \mathrm{Cl}_{10}\right] .4 \mathrm{H}_{2} \mathrm{O}$. Journal of Inorganic Biochemistry, 71, 43-60.

Wu, G., Wang, G., Fu, X., \& Zhu, L. (2003). Synthesis, Crystal Structure, Stacking Effect and Antibacterial Studies of a Novel Quaternary Copper (II) Complex with Quinolone Molecules, 8, 287-296. http://dx.doi.org/10.3390/80200287

\section{Notes}

Note 1. Measured in $10^{-3} \mathrm{M}$ DMSO solutions at room temperature.

Note $2 . \mathrm{s}=$ strong, $\mathrm{w}=$ weak, $\mathrm{m}=$ medium, $\mathrm{sh}=$ shoulder, $\mathrm{v}=$ very, $\mathrm{br}=$ broad

Note 3. $v$, stretching; $\delta$, bending.

Note 4. $\Delta v=v_{\text {as }}\left(\mathrm{COO}^{-}\right)-v_{\mathrm{s}}\left(\mathrm{COO}^{-}\right)$.

Note 5. As $v(\mathrm{COOH})$.

Note 6. Units of parameters: $E$ in kJ mol${ }^{-1}, A$ in s${ }^{-1}, \Delta S$ in $\mathrm{J} \mathrm{mol}^{-1} \mathrm{~K}^{-1}, \Delta H$ and $\Delta G$ in kJ mol${ }^{-1}$.

Note 7. (-) NO activity, $(+)$ mild activity, $(++)$ moderate activity, $(+++)$ marked activity, $(++++)$ strong marked activity.

Table 1. Elemental analysis and physical properties of the compounds

\begin{tabular}{|l|l|l|l|l|l|l|l|l|l|l|}
\hline Compound & $\begin{array}{l}\text { Molecular } \\
\text { weight }\end{array}$ & $\begin{array}{l}\text { Yield } \\
(\%)\end{array}$ & Color & $\begin{array}{l}\mathrm{mp} \\
\left({ }^{\circ} \mathrm{C}\right)\end{array}$ & \multicolumn{3}{|l|}{ Analysis (\%) found (calculated) } & $\begin{array}{l}\Lambda^{\text {Note } 1 .} \\
\left(\Omega^{-1} \mathrm{~cm}^{2} \mathrm{~mol}^{-1}\right)\end{array}$ \\
\hline & & & & & $\mathrm{C}$ & $\mathrm{H}$ & $\mathrm{N}$ & $\mathrm{Cl}$ & $\mathrm{M}$ & \\
\hline $\begin{array}{l}\mathrm{NFX} \\
\mathrm{C}_{16} \mathrm{H}_{18} \mathrm{FN}_{3} \mathrm{O}_{3}\end{array}$ & 319 & - & Yellow & 232 & $\begin{array}{l}59.45 \\
(60.18)\end{array}$ & $\begin{array}{l}5.54 \\
(5.68)\end{array}$ & $\begin{array}{l}12.89 \\
(13.16)\end{array}$ & - & - & 10.16 \\
\hline$\left[\mathrm{Th}(\mathrm{NFX})_{2} \mathrm{Cl}_{4}\right]$ & 1012 & 74 & White & $\begin{array}{l}> \\
300\end{array}$ & $\begin{array}{l}37.96 \\
(37.94)\end{array}$ & $\begin{array}{l}3.58 \\
(3.56)\end{array}$ & $\begin{array}{l}8.30 \\
(8.30)\end{array}$ & $\begin{array}{l}14.01 \\
(14.03)\end{array}$ & $\begin{array}{l}22.92 \\
(22.92)\end{array}$ & 85.00 \\
\hline$\left[\mathrm{Zr}(\mathrm{NFX})_{2} \mathrm{Cl}_{2}\right] \mathrm{Cl}_{2}$ & 871.23 & 76 & White & $\begin{array}{l}> \\
300\end{array}$ & $\begin{array}{l}44.09 \\
(44.08)\end{array}$ & $\begin{array}{l}4.16 \\
(4.13)\end{array}$ & $\begin{array}{l}9.64 \\
(9.64)\end{array}$ & $\begin{array}{l}16.27 \\
(16.30)\end{array}$ & $\begin{array}{l}10.47 \\
(10.47)\end{array}$ & 73.00 \\
\hline$\left[\mathrm{VO}(\mathrm{NFX})_{2}\right] \mathrm{SO}_{4}$ & 810 & 73 & $\begin{array}{l}\text { Greenish } \\
\text { brown }\end{array}$ & $\begin{array}{l}> \\
300\end{array}$ & $\begin{array}{l}47.64 \\
(47.40)\end{array}$ & $\begin{array}{l}4.53 \\
(4.45)\end{array}$ & $\begin{array}{l}10.48 \\
(10.37)\end{array}$ & - & $\begin{array}{l}7.41 \\
(6.95)\end{array}$ & 87.20 \\
\hline
\end{tabular}


Table 2. IR frequencies ${ }^{\text {Note } 2 .}\left(\mathrm{cm}^{-1}\right)$ and tentative assignments ${ }^{\text {Note } 3 .}$ for: NFX and $\mathrm{Th}(\mathrm{IV}), \mathrm{Zr}(\mathrm{IV})$, and V(IV) compounds

\begin{tabular}{|c|c|c|c|c|}
\hline NFX & $\operatorname{Th}(\mathrm{IV})$ & $\mathrm{Zr}(\mathrm{IV})$ & $\mathrm{V}(\mathrm{IV})$ & Assignments \\
\hline $3399 \mathrm{~ms}$ & $3390 \mathrm{~m}, \mathrm{br}$ & $3903 \mathrm{w}, 3715 \mathrm{w}, 3396 \mathrm{~m}, \mathrm{br}$ & $3685 \mathrm{w}, 3435 \mathrm{~m}, 3317 \mathrm{~m}$ & $\mathrm{v}(\mathrm{N}-\mathrm{H})+\mathrm{v}_{\mathrm{as}}(\mathrm{O}-\mathrm{H}) ; \mathrm{H}_{2} \mathrm{O}$ \\
\hline $3267 \mathrm{vw}, 3228 \mathrm{vw}, 3189 \mathrm{vw}$, & $3253 \mathrm{~m}, \quad 3120 \mathrm{vw}, \quad 2933 \mathrm{vw}$ & $2988 \mathrm{vw}, 2845 \mathrm{vw}, 2356 \mathrm{~m}, 2320$ & $2967 \mathrm{vw}, 2883 \mathrm{vw}, 2817 \mathrm{vw}$ & $\mathrm{v}_{\mathrm{s}}(\mathrm{O}-\mathrm{H}) ; \mathrm{H}_{2} \mathrm{O}, \mathrm{v}(\mathrm{C}-\mathrm{H}), \mathrm{v}(\mathrm{N}-\mathrm{H}), \mathrm{v}\left(-\mathrm{NH}_{2}{ }^{+}\right)$ \\
\hline $3130 \mathrm{vw}, 3021 \mathrm{w}, 2927 \mathrm{~m}$, & $2791 \mathrm{vw}, 2375 \mathrm{w}, 2348 \mathrm{vw}$ & $\mathrm{mw}$ & $2344 \mathrm{~m}, 2314 \mathrm{~m}, \mathrm{sh}$ & \\
\hline \multicolumn{5}{|l|}{$2823 \mathrm{w}, 2796 \mathrm{w}, 2764 \mathrm{w}}$, \\
\hline \multicolumn{5}{|l|}{$2723 \mathrm{~m}, 2696 \mathrm{vw}, 2654 \mathrm{w}$} \\
\hline \multicolumn{5}{|l|}{$2617 \mathrm{w}, 2511 \mathrm{w}, 2468 \mathrm{~m}$} \\
\hline $1727 \mathrm{sh}, 1716 \mathrm{~ms}$ & $1688 \mathrm{~m}$ & $1679 \mathrm{w}$ & $1657 \mathrm{w}$ & $v(\mathrm{C}=\mathrm{O}):(\mathrm{COOH})$ \\
\hline $1630 \mathrm{vs}, 1552 \mathrm{w}$ & $1617 \mathrm{~m}, 1576 \mathrm{~s}$ & $1610 v s, 1579 v s$ & $1615 \mathrm{~ms}, 1583 \mathrm{~s}$ & $\mathrm{v}(\mathrm{C}=\mathrm{O})+\delta_{\mathrm{b}}\left(\mathrm{H}_{2} \mathrm{O}\right)$ phenyl breathing modes \\
\hline $1482 \mathrm{vs}, 1454 \mathrm{~m}$ & $1495 \mathrm{vs}, 1458 \mathrm{~m}$ & $1477 \mathrm{~m}, 1447 \mathrm{~m}$ & $1497 \mathrm{vs}$ & $\mathrm{CH}$ : deformation of $-\mathrm{CH}_{2}$ \\
\hline $1396 \mathrm{~s}$ & $1385 \mathrm{~s}, 1355 \mathrm{~m}$ & $1387 \mathrm{~s}, 1361 \mathrm{~m}$ & 1381 vs, $1358 \mathrm{~s}$ & $\mathrm{v}_{\mathrm{s}}(\mathrm{COO})+\mathrm{v}(\mathrm{N}-\mathrm{O}): \mathrm{NO}_{3}{ }^{-}$ \\
\hline $1307 \mathrm{vw}$ & $1310 \mathrm{~m}$ & $1317 \mathrm{~m}$ & - & $\delta_{b}\left(\mathrm{CH}_{2}\right)$ \\
\hline $1277 \mathrm{vw}, 1263 \mathrm{~s}, 1248 \mathrm{vw}$ & $1245 \mathrm{vw}$ & $1285 \mathrm{~m}$ & $1252 \mathrm{~ms}$ & $v(\mathrm{C}-\mathrm{C})$ \\
\hline $1201 \mathrm{~m}, 1192 \mathrm{~m}$ & $1207 \mathrm{vw}$ & $1188 \mathrm{w}$ & $1195 \mathrm{w}$ & $\mathrm{v}(\mathrm{C}-\mathrm{O}) \mathrm{v}(\mathrm{C}-\mathrm{N})$ \\
\hline $1153 \mathrm{vw}, 1142 \mathrm{w}, 1132 \mathrm{w}$, & $1151 \mathrm{w}, 1091 \mathrm{w} 1068 \mathrm{w}$ & $1144 \mathrm{vw}$ & $1036 \mathrm{vw}$ & $\delta_{\mathrm{r}}\left(\mathrm{CH}_{2}\right)$ \\
\hline \multicolumn{5}{|l|}{$1115 \mathrm{w}, 1095 \mathrm{~m}, 1076 \mathrm{~m}$} \\
\hline \multicolumn{5}{|l|}{$1051 \mathrm{vw}, 1036 \mathrm{~ms}, 1024 \mathrm{w}$} \\
\hline \multicolumn{5}{|l|}{$1005 \mathrm{~m}, 982 \mathrm{~m}$} \\
\hline $750 \mathrm{~s}, 706 \mathrm{~m}$ & $760 \mathrm{~m}, 718 \mathrm{~m}$ & $763 \mathrm{~m}, 705 \mathrm{~m}$ & $776 \mathrm{~m}, 727 \mathrm{w}$ & $\delta_{b}\left(\mathrm{COO}^{-}\right)$ \\
\hline $667 \mathrm{w}, 631 \mathrm{w}, \mathrm{br}, 569 \mathrm{~ms}$ & $679 \mathrm{w}, 645 \mathrm{w}, 502 \mathrm{w}, 471 \mathrm{vw}$ & $651 \mathrm{mw}, 627 \mathrm{vw}, 563 \mathrm{~m}, 531 \mathrm{vw}$, & $689 \mathrm{~ms}, 641 \mathrm{w}, 579 \mathrm{w}, 546 \mathrm{w}$, & $v(\mathrm{M}-\mathrm{O})+$ ring deformation \\
\hline $524 \mathrm{w}, 499 \mathrm{~m}, 474 \mathrm{~m}$ & & $489 \mathrm{w}, 465 \mathrm{w}$ & $503 \mathrm{vw}, 491 \mathrm{w}, 466 \mathrm{vw}$ & \\
\hline $453 \mathrm{vw}, 430 \mathrm{~ms}$ & & & & \\
\hline
\end{tabular}

Table 3. Characteristic absorptions of carboxylate group (in $\mathrm{cm}^{-1}$ ) and $\Delta v$ values

\begin{tabular}{lllll}
\hline Compound & $v(\mathrm{C}=\mathrm{O})_{\mathrm{p}}$ & $v\left(\mathrm{COO}^{-}\right)_{\text {asym }}$ & $v\left(\mathrm{COO}^{-}\right)_{\text {sym }}$ & $\Delta v^{\text {Note } 4 .}$ \\
\hline $\mathrm{NFX}$ & 1630 & $1727^{\text {Note }} 5$ & - & - \\
{$\left[\mathrm{Th}(\mathrm{NFX})_{2} \mathrm{Cl}_{4}\right]$} & 1617 & 1576 & 1380 & 196 \\
{$\left[\mathrm{Zr}(\mathrm{NFX})_{2} \mathrm{Cl}_{2}\right] \mathrm{Cl}_{2}$} & 1610 & 1579 & 1382 & 197 \\
{$\left[\mathrm{VO}(\mathrm{NFX})_{2}\right] \mathrm{SO}_{4}$} & 1615 & 1583 & 1381 & 202 \\
\hline
\end{tabular}

Table 4. ${ }^{1} \mathrm{H}$ NMR spectral data of free NFX and $\left[\mathrm{Th}(\mathrm{NFX})_{2} \mathrm{Cl}_{4}\right]$ complex

\begin{tabular}{lll}
\hline $\mathrm{NFX}$ & {$\left[\mathrm{Th}\left(\mathrm{NFX}_{2} \mathrm{Cl}_{4}\right]\right.$} & Assignments \\
\hline 1.13 & 1.70 & $\delta \mathrm{H},-\mathrm{CH}_{3}$ \\
2.0 & 2.10 & $\delta \mathrm{H},-\mathrm{NH} ;$ piperazine \\
- & 2.50 & $\delta \mathrm{H},-{ }^{-} \mathrm{NH}_{2}$ \\
- & 3.9 & $\delta \mathrm{H},-{ }^{-} \mathrm{NH}_{2}$ \\
$2.78,3.10,3.47$ & - & $\delta \mathrm{H},-\mathrm{CH}_{2} ;$ piperazine $\delta \mathrm{H},-\mathrm{CH}_{2} ;-\mathrm{CH}_{2} \mathrm{CH}_{3}$ \\
$5.93,7.12,8.01$ & $7.2,7.3,7.7,8.1,8.2,8.3$ & $\delta \mathrm{H},-\mathrm{CH}$ aromatic \\
11.00 & 8.8 & $\delta \mathrm{H},-\mathrm{COOH}$ \\
\hline
\end{tabular}


Table 5. Thermo analytical results for the investigated compounds

\begin{tabular}{|c|c|c|c|c|c|c|}
\hline \multirow[b]{2}{*}{ Samples } & \multirow[b]{2}{*}{ Stage } & \multirow{2}{*}{$\begin{array}{l}\text { TG } \\
\text { results } \\
\text { temp. } \\
\text { peak }\left({ }^{\circ} \mathrm{C}\right)\end{array}$} & \multirow{2}{*}{$\begin{array}{l}\text { DTG results } \\
\text { temp. range } \\
\left({ }^{\circ} \mathrm{C}\right)\end{array}$} & \multicolumn{2}{|c|}{ Weight loss $(\%)$} & \multirow[b]{2}{*}{ Evolved moiety } \\
\hline & & & & Found & $\begin{array}{l}\text { Calcul- } \\
\text { ated }\end{array}$ & \\
\hline NFX & I & $25-270$ & 125 & 8.38 & 8.78 & $\mathrm{C}_{2} \mathrm{H}_{4}$ \\
\hline$\left(\mathrm{C}_{16} \mathrm{H}_{18} \mathrm{~N}_{3}\right.$ & II & $270-575$ & 335 & 69.80 & 70.22 & $\mathrm{HF}+4 \mathrm{C}_{2} \mathrm{H}_{2}+\mathrm{CO}+\mathrm{CO}_{2}+\mathrm{N}_{2}$ \\
\hline $\left.\mathrm{O}_{3} \mathrm{~F}\right)$ & III & $575-726$ & 650 & 19.56 & 21.00 & $2 \mathrm{C}_{2} \mathrm{H}_{2}+0.5 \mathrm{H}_{2}+0.5 \mathrm{~N}_{2}$ \\
\hline \multirow{4}{*}{$\begin{array}{l}\mathrm{Th} / \mathrm{NFX} \\
\left(\mathrm{C}_{32} \mathrm{H}_{36} \mathrm{~N}_{6}\right. \\
\left.\mathrm{O}_{6} \mathrm{FCl}_{4}\right) \mathrm{Th}\end{array}$} & I & $25-260$ & $50,108,218$ & 11.84 & 12.15 & $2 \mathrm{C}_{2} \mathrm{H}_{2}+\mathrm{Cl}_{2}$ \\
\hline & II & $260-530$ & $308,377,455$ & 37.69 & 38.04 & $5 \mathrm{C}_{2} \mathrm{H}_{2}+\mathrm{Cl}_{2}+2 \mathrm{HF}+2 \mathrm{~N}_{2}+2 \mathrm{NO}+\mathrm{CO}$ \\
\hline & III & $530-900$ & 580 & 19.11 & 18.97 & $7 \mathrm{C}_{2} \mathrm{H}_{2}+\mathrm{CO}+4 \mathrm{H}_{2}$ \\
\hline & Residue & & & 31.36 & 30.83 & $\mathrm{ThO}_{2}+4 \mathrm{C}$ \\
\hline $\mathrm{Zr} / \mathrm{NFX}$ & I & $25-250$ & 60,298 & 17.61 & 18.19 & $2 \mathrm{C}_{2} \mathrm{H}_{2}+3 / 2 \mathrm{Cl}_{2}$ \\
\hline$\left(\mathrm{C}_{32} \mathrm{H}_{36} \mathrm{~N}_{6}\right.$ & II & $250-900$ & 553 & 68.67 & 67.66 & $13 \mathrm{C}_{2} \mathrm{H}_{2}+1 / 2 \mathrm{Cl}_{2}+2 \mathrm{HF}+2 \mathrm{~N}_{2}+2 \mathrm{NO}+2 \mathrm{CO}+2 \mathrm{H}_{2}$ \\
\hline $\left.\mathrm{O}_{6} \mathrm{FCl}_{4}\right) \mathrm{Zr}$ & Residue & & & 13.71 & 14.14 & $\mathrm{ZrO}_{2}$ \\
\hline \multirow{4}{*}{$\begin{array}{l}\mathrm{V} / \mathrm{NFX} \\
\left(\mathrm{C}_{32} \mathrm{H}_{36} \mathrm{~N}_{6}\right. \\
\left.\mathrm{O}_{10} \mathrm{FS}\right) \mathrm{V}\end{array}$} & I & $25-210$ & 60 & 15.06 & 14.81 & $2 \mathrm{C}_{2} \mathrm{H}_{2}+\mathrm{SO}_{2}$ \\
\hline & II & $210-520$ & 260 & 68.38 & 68.15 & $12 \mathrm{C}_{2} \mathrm{H}_{2}+2 \mathrm{HF}+2 \mathrm{~N}_{2}+2 \mathrm{NO}+\mathrm{CO}+1 / 2 \mathrm{CO}_{2}+\mathrm{O}_{2}$ \\
\hline & III & $520-900$ & 374,445 & 1.68 & 1.73 & $1 / 2 \mathrm{CO}$ \\
\hline & Residue & & & 14.88 & 15.31 & $\mathrm{VO}_{2.5}+2 \mathrm{C}$ \\
\hline
\end{tabular}

Table 6. Thermal behavior and kinetic parameters determined using the Coats-Redfern (CR) and Horowitz-Metzger ((HM)

\begin{tabular}{|c|c|c|c|c|c|c|c|c|c|}
\hline \multirow{2}{*}{ Compounds } & \multirow{2}{*}{$\begin{array}{l}\text { Radius } \\
\text { metal } \\
\text { ion/pm }\end{array}$} & \multirow{2}{*}{$\mathrm{T}_{\mathrm{s}}(\mathrm{K})$} & \multirow{2}{*}{ Method } & \multicolumn{6}{|c|}{ Parameters Note 6.} \\
\hline & & & & $E^{*}$ & $A$ & $\Delta S^{*}$ & $\Delta H^{*}$ & $\Delta G^{*}$ & $r$ \\
\hline \multirow{2}{*}{ NFX (16) } & \multirow{2}{*}{ - } & \multirow{2}{*}{-} & $\mathrm{CR}$ & $9.36 \times 10^{4}$ & $2.00 \times 10^{1}$ & $-5.01 \times 10^{1}$ & $9.03 \times 10^{4}$ & $1.10 \times 10^{5}$ & 0.9853 \\
\hline & & & HM & $9.66 \times 10^{4}$ & $8.68 \times 10^{1}$ & $-3.79 \times 10^{1}$ & $9.33 \times 10^{4}$ & $1.08 \times 10^{5}$ & 0.9817 \\
\hline \multirow{2}{*}{ Th / NFX } & \multirow{2}{*}{108} & \multirow{2}{*}{550} & $\mathrm{CR}$ & $8.19 \times 10^{4}$ & $1.26 \times 10^{6}$ & $-1.37 \times 10^{2}$ & $1.31 \times 10^{5}$ & $2.44 \times 10^{5}$ & 0.9855 \\
\hline & & & $\mathrm{HM}$ & $1.46 \times 10^{5}$ & $1.23 \times 10^{7}$ & $-1.18 \times 10^{2}$ & $1.39 \times 10^{5}$ & $2.36 \times 10^{5}$ & 0.9777 \\
\hline \multirow{2}{*}{$\mathrm{Zr} / \mathrm{NFX}$} & \multirow{2}{*}{86} & \multirow{2}{*}{344} & $\mathrm{CR}$ & $1.38 \times 10^{5}$ & $3.59 \times 10^{4}$ & $-1.64 \times 10^{2}$ & $7.67 \times 10^{4}$ & $1.78 \times 10^{5}$ & 0.9812 \\
\hline & & & $\mathrm{HM}$ & $8.82 \times 10^{4}$ & $2.02 \times 10^{5}$ & $-1.49 \times 10^{2}$ & $8.30 \times 10^{4}$ & $1.75 \times 10^{5}$ & 0.9806 \\
\hline \multirow{2}{*}{ V/NFX } & \multirow{2}{*}{72} & \multirow{2}{*}{377} & $\mathrm{CR}$ & $1.73 \times 10^{5}$ & $7.53 \times 10^{11}$ & $-2.40 \times 10^{1}$ & $1.67 \times 10^{5}$ & $1.83 \times 10^{5}$ & 0.9980 \\
\hline & & & HM & $1.93 \times 10^{5}$ & $4.64 \times 10^{13}$ & $1.02 \times 10^{1}$ & $1.88 \times 10^{5}$ & $1.81 \times 10^{5}$ & 0.9955 \\
\hline
\end{tabular}


Table 7. Antibacterial and antifungal activities ${ }^{\text {Note } 7 .}$ data for NFX and its compounds

\begin{tabular}{|c|c|c|c|c|c|c|}
\hline \multirow{3}{*}{ Compound } & \multicolumn{6}{|c|}{ Microbial species } \\
\hline & Bacteria & & & Fungi & & \\
\hline & $\begin{array}{l}\text { Bacillus } \\
\text { subtilis }\end{array}$ & P. aeruginosa & E. coli & $\begin{array}{l}\text { Aspergills } \\
\text { flavus }\end{array}$ & $\begin{array}{l}\text { Fusarium } \\
\text { solani }\end{array}$ & $\begin{array}{l}\text { Penicillium } \\
\text { verrcosum }\end{array}$ \\
\hline NFX & ++++ & + & - & - & - & ++ \\
\hline$\left[\mathrm{Th}(\mathrm{NFX})_{2} \mathrm{Cl}_{4}\right]$ & - & ++++ & ++++ & ++ & ++++ & ++ \\
\hline$\left[\mathrm{Zr}(\mathrm{NFX})_{2} \mathrm{Cl}_{2}\right] \mathrm{Cl}_{2}$ & - & ++ & +++ & + & ++++ & + \\
\hline$\left[\mathrm{VO}(\mathrm{NFX})_{2}\right] \mathrm{SO}_{4}$ & - & ++ & +++ & +++ & ++ & +++ \\
\hline Control (DMSO) & - & - & - & - & - & - \\
\hline
\end{tabular}

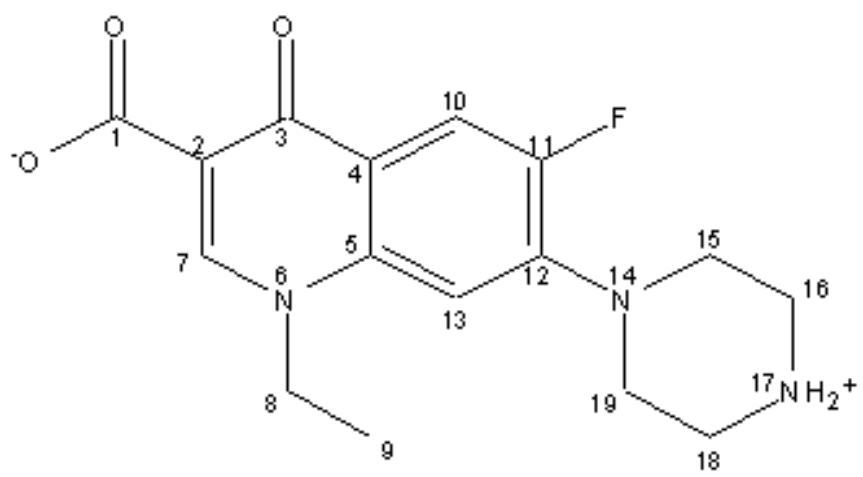

Figure 1. Structure of Norfloxacin (NFX) and its zwitterionic structure 
(a)<smiles>CCn1cc(C(=O)OC(Cl)(Cl)Cl)c(=O)c2cc(N3CC[NH2+]CC3)c(N3CC[NH2+]CC3)cc21</smiles>

(b)

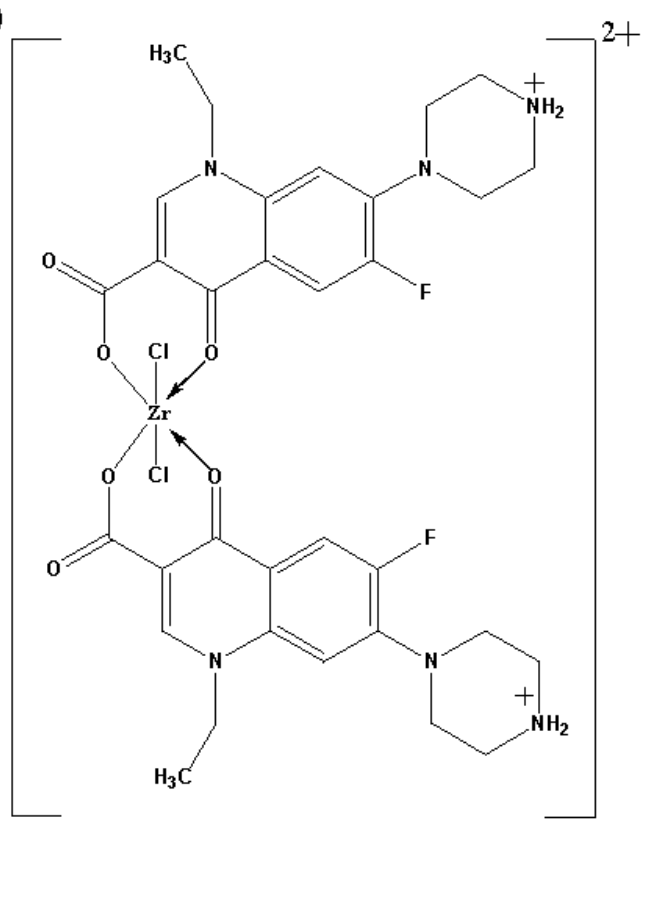

(c)

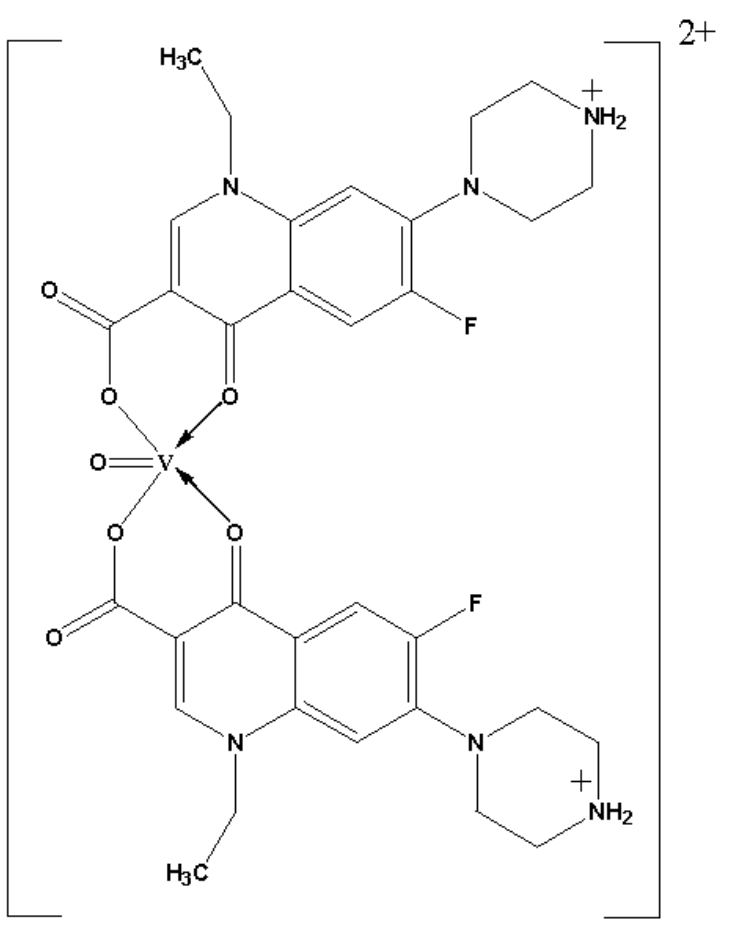

Figure 2. Suggested structure of (a) Th(IV), (b) Zr(IV), and (c) V(IV) - NFX complexes 

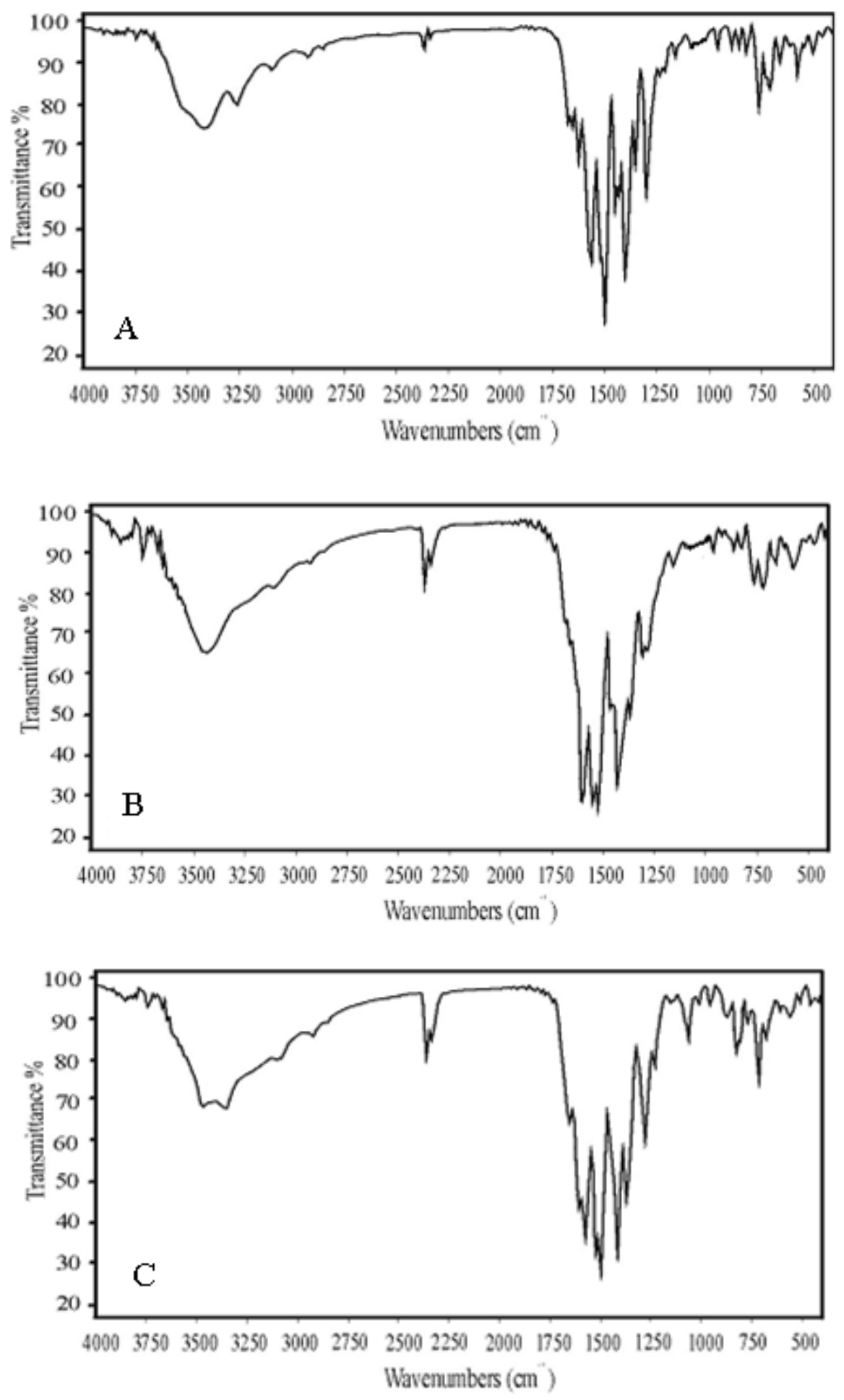

Figure 3. Infrared spectra of: (A) $\left[\mathrm{Th}(\mathrm{NFX})_{2} \mathrm{Cl}_{4}\right]$ complex; (B) $\left[\mathrm{Zr}(\mathrm{NFX})_{2} \mathrm{Cl}_{2}\right] \mathrm{Cl}_{2}$ complex; (C) $\left[\mathrm{VO}(\mathrm{NFX})_{2}\right] \mathrm{SO}_{4}$ complex 

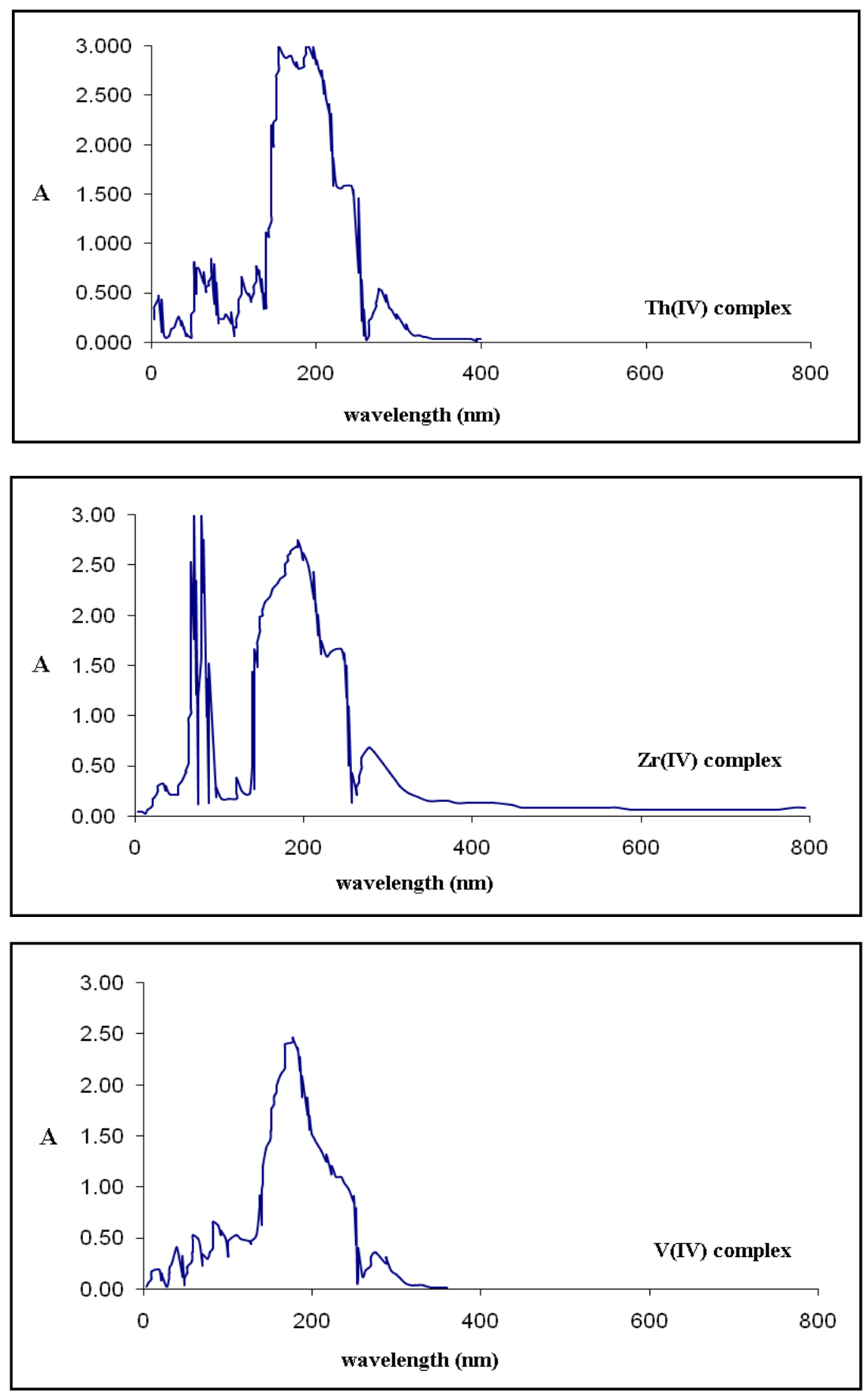

Figure 4. Electronic spectra of norfloxacin complexes 


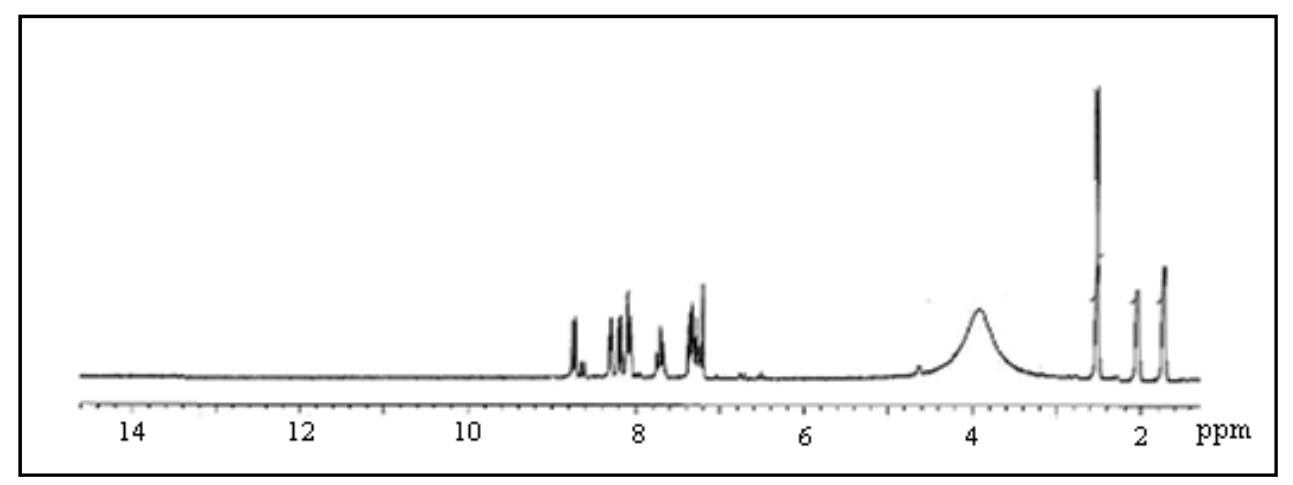

Figure 5. ${ }^{1} \mathrm{H}$ NMR spectra of $\left[\mathrm{Th}(\mathrm{NFX})_{2} \mathrm{Cl}_{2}\right]$ complex
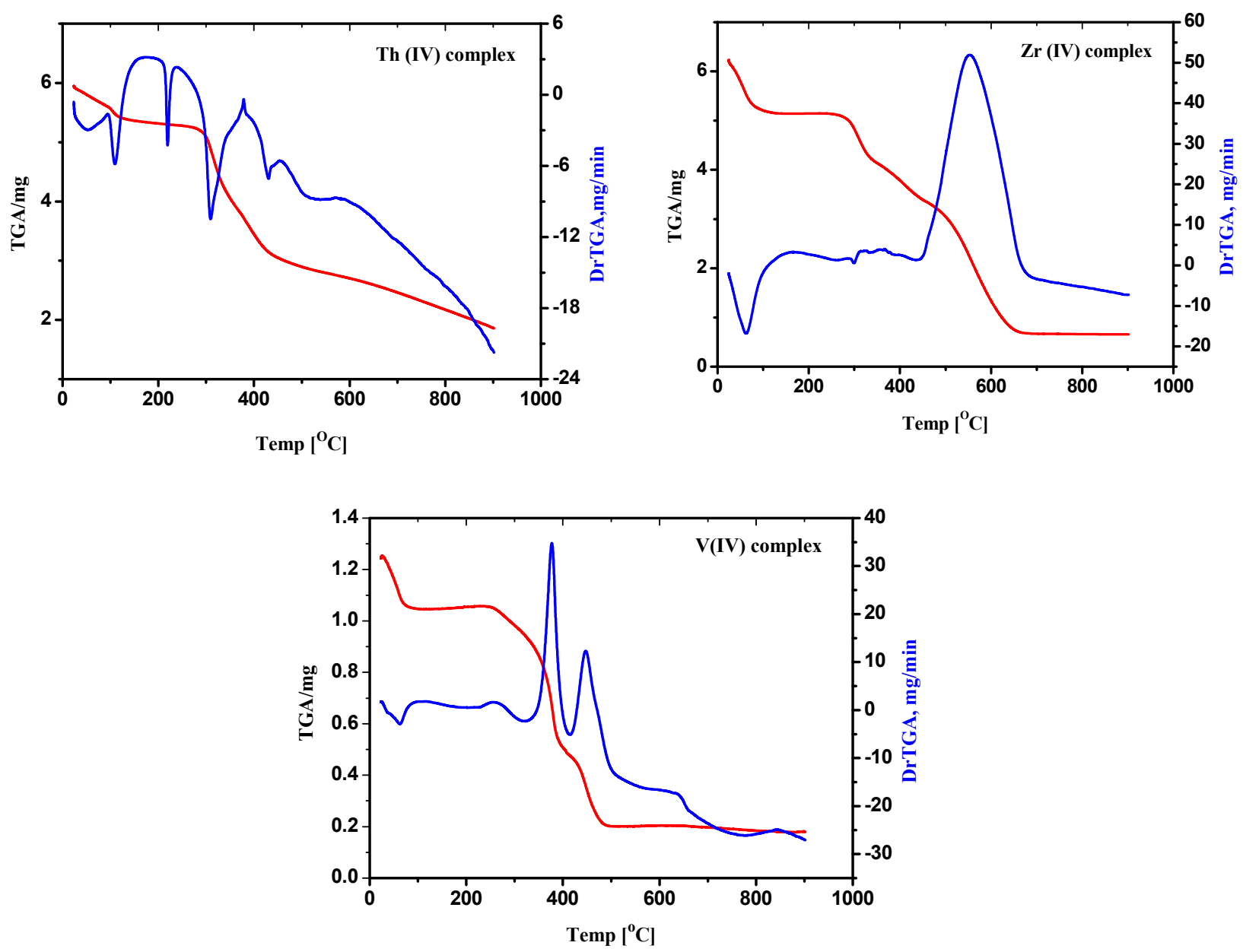

Figure 6. TG and DTG curves of Norfloxacin complexes 

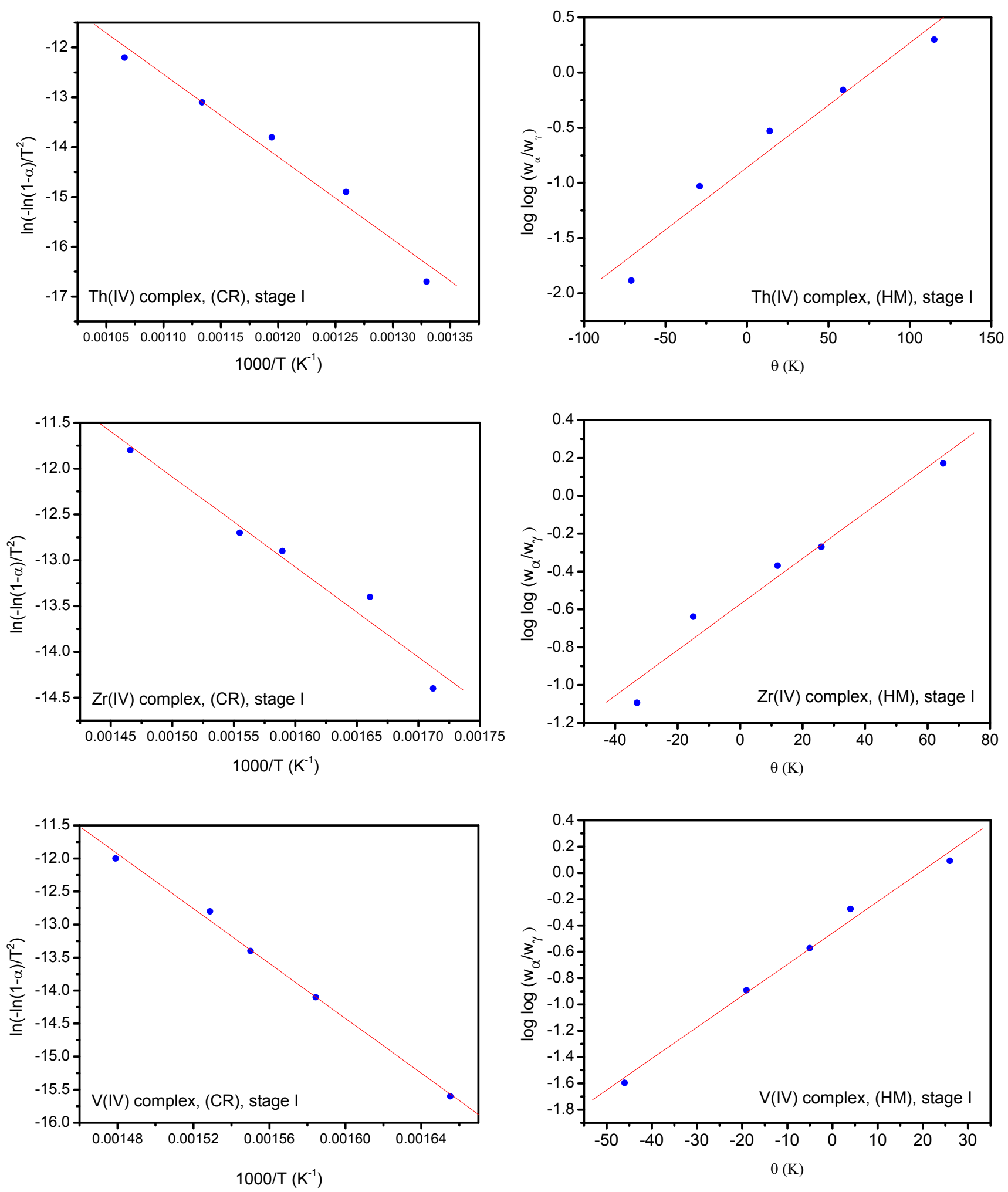

Figure 7. The diagrams of kinetic parameters of NFX complexes using Coats-Redfern (CR) and Horowitz-Metzger (HM) equations 